\title{
Kinerja Pemerintah Desa Dalam Pengelolaan Dana Desa (Studi Pada Desa Dore Kecamatan Palibelo Kabupaten Bima)
}

\author{
Ika Asmawati ${ }^{1}$ \\ Prayitno Basuki ${ }^{2}$ \\ Ahmad Rifa'i ${ }^{3}$
}

${ }^{1}$ Program Magister Akuntansi Fakultas Ekonomi dan Bisnis Universitas

Mataram (Unram), NTB, Indonesia.

email: mancandailombok@gmail.com/ Telp : -

${ }^{2}$ Program Magister Akuntansi Fakultas Ekonomi dan Bisnis Universitas

Mataram (Unram), NTB, Indonesia.

${ }^{3}$ Program Magister Akuntansi Fakultas Ekonomi dan Bisnis Universitas

Mataram (Unram), NTB, Indonesia.

\begin{abstract}
ABSTRAK
Penelitian ini bertujuan untuk menganalisis kinerja Pengelolaan Dana Desa di Desa Dore Bima. Dalam penelitian ini, peneliti berfokus pada kinerja aparatur desa.Penelitian ini menggunakan pendekatan kualitatif, menggunakan teknik pengamatan,wawancara, dan dokumentasi terhadap informan sebanyak lima (5) orang. Hasil penelitian ini menunjukkan dari 5 (lima) dimensi yang diteliti, 4 (empat) dimensi tidak berfungsi dengan baik seperti dimensi tanggung jawab, pelayanan kualitas, produktivitas dan akuntabilitas sedangkandimensi responsivitasbekerja dengan cukup baik. Berdasarkan temuan tersebut direkomendasikan perbaikan seperti pelatihan atau kursus untuk aparat desa dan penyediaan media sebagai alat untuk mempertanggungjawabkan pengelolaan dana desa sehinggakinerja pemerintah Desa Dore diharapkan dapat lebih optimal dari sebelumnya.
\end{abstract}

Kata Kunci: Produktivitas, Kualitas Layanan, Responsivitas, Responsibilitas, Akuntabilitas

\begin{abstract}
This research aimed to analyze qualitatively the performance of Village Fund executeat Dore Village Bima Regency. In this study, researchers focused on the performance of village officials. This study used a qualitative approach by observation, interview, and documentation techniques to the informant as much as five (5) persons. The research result showed that the Performance Analysis Management of Village Fund at Dore Village Bima Regency had not yet run well as from 5 (five) dimention investigated, 4(four) dimensions did not work well such as dimension of responsibility, service quality, productivity and accountability but one was only that worked well enough is responsiveness.Based on these findings, improvements such as training or courses are recommended for village officials and the provision of media as a tool to account for the management of village funds so that the performance of the Dore Village government is expected to be more optimal than before.

Keywords: Productivity; Service Quality; Responsiveness; Responsibility; Accountability
\end{abstract}


Ika Asmawati, Prayitno Basuki, dan Ahmad Rifa'i. Kinerja...

\section{PENDAHULUAN}

Indonesia terbagi menjadi 34 Propinsi dengan hak otonomi untuk mengatur daerahnya masing-masing. Menurut Undang-Undang No.32 Tahun 2004 tentang Pemerintahan Daerah, Otonomi Daerah didefinisikan sebagai hak, wewenang dan kewajiban daerah otonom untuk mengatur dan mengurus sendiri urusan pemerintahan dan kepentingan masyarakat setempat sesuai dengan peraturan perundang-undangan yang berlaku.

Otonomi daerah ditujukan untuk menjadikan pemerintah yang efektif dan efisien dalam melaksanakan kegiatan pemerintahan, pembangunan dan pelayanan kepada masyarakat, serta dalam memotivasi masyarakat dan pemerintah daerah masing-masing agar memikul tanggungjawab dan kepedulian yang besar terhadap kehidupan masyarakat dan lingkungan daerahnya. Secara esensi sebenarnya kemandirian tersebut harus dimulai dari level pemerintahan ditingkat paling bawah, yaitu Desa. Pemerintah desa diyakini lebih mampu melihat prioritas kebutuhan masyarakat dibandingkan pemerintah kabupaten yang secara nyata memiliki ruang lingkup permasalahan lebih luas dan rumit (Rosalinda, 2014).

Peraturan perundang-undangan tentang Desa diawali dengan Undang-undang No 5 Tahun 1979 tentang Pemerintahan Desa dan diatur lebih lanjut dalam Undang-Undang No 32 Tahun 2004 tentang Pemerintahan Daerah dan diperbaharui dengan Undang-Undang No 6 Tahun 2014 tentang Desa yang menyatakan bahwa "Desa adalah desa dan desa adat atau disebut dengan nama lain, selanjutnya disebut desa, adalah kesatuan masyarakat hukum yang memiliki batas wilayah yang berwenang untuk mengatur dan mengurus urusan pemerintah, 
kepentingan masyarakat setempat berdasarkan prakarsa masyarakat, hak asal usul dan/atau hak tradisional yang diakui dan dihormati dalam sistem pemerintahan Negara Kesatuan Republik Indonesia”.

Pembangunan desa mempunyai peranan penting dan strategis dalam rangka pembangunan nasional dan pembangunan daerah, karena didalamnya terkandung unsur pemerataan pembangunan dan hasil-hasilnya serta menyentuh secara langsung kepentingan sebagian besar masyarakat yang bermukim di pedesaan dalam rangka upaya meningkatkan kesejahteran mereka (Sofiyanto, et al, 2016). Pembangunan desa dapat dilakukan berdasarkan program pembangunan yang di peruntukkan khusus bagi desa dan kelurahan, yang berpijak pada desa di kenal dengan dana pembangunan desa.

Dana desa adalah dana APBN yang diperuntukkan bagi desa yang ditransfer melalui APBD Kabupaten/Kota dan diprioritaskan untuk pelaksanaan pembangunan dan pemberdayaan masyarakat desa (www.kemenkeu.go.id). Dana desa merupakan salah satu program pemerintah untuk mewujudkan pemerataan pembangunan, terutama bagi des a yang termasuk dalam kategori desa tertinggal.

Dana desa yang dikucurkan pemerintah untuk tahun anggaran 2017 secara nasional berjumlah Rp 60 Triliun dan disalurkan untuk 74.954 Desa yang tersebar dalam 34 Propinsi di Indonesia. Besaran dana desa secara nasional mengalami kenaikan tiga kali lipat dari tahun anggaran 2015 (Rp 20,76 Triliun) dan mengalami kenaikan 28\% dari dana desa tahun 2016 ( $\operatorname{Rp} 49,96$ Triliun).Untuk Propinsi NTB dana desa juga mengalami kenaikan, tahun 2015 sebesar Rp 
Ika Asmawati, Prayitno Basuki, dan Ahmad Rifa'i. Kinerja...

301.797.520.000 naik menjadi Rp 677.494.427.000 pada tahun 2016 dan menjadi Rp 865.014.066.000 pada tahun 2017.

Tahun 2017 untuk Propinsi Nusa Tenggara Barat (NTB) 995 desa mendapatkan dana desa (antaranews.com). Untuk Kabupaten Bima pada tahun 2017, 191 desa yang tersebar di 18 Kecamatan mendapatkan dana desa. Dan diantaranya 118 desa mengalami penundaan pencairan dana desa (DDA),salah satunya adalah desa Dore di Wilayah Kecamatan Palibelo. Dana desa yang merupakan salah satu jenis bantuan keuangan selalu menjadi topik menarik untuk dibahas. Menurut artikel yang bersumber dari www.lombokita.com dikatakan bahwa munculnya persoalan yang terjadi dalam pengelolaan dana desa (DD) maupun alokasi dana desa di wilayah Propinsi Nusa Tenggara Barat disebabkan karena Sumber Daya Manusia (SDM) yang dimiliki pemerintah desa masih kurang menguasai pengelolaannya, dan dapat disimpulkan bahwa besarnya dana desa yang harus dikelola oleh pemerintah desa belum selaras dengan kemampuan SDM sehingga dianggap menjadi penghambat di lapangan, selain karena keberadaan regulasi yang relatif baru dan belum sepenuhnya dipahami oleh pelaksana di daerah yaitu pemerintah desa. Artinya dapat diduga bahwa sebagian besar desa yang ada di Indonesia melakukan pemilihan kepala desa secara aklamasi kekeluargaan, tanpa memperhatikan kemampuan atau kompetensi yang akan sangat mempengaruhi kinerjanya, hal ini juga ditemukan di Lapangan di Desa Dore Kecamatan Palibelo Kabupaten Bima.

Data yang diperoleh dari Dinas Pemberdayaan Masyarakat Desa Kabupaten Bima untuk tahun 2017, dari rata-rata dana desa Rp 799.420.330 yang diberikan 
untuk setiap desa di Kecamatan Palibelo, desa Dore hanya mendapatkan transfer dana desa sebesar Rp 767.200.695,27 paling rendah dibandingkan dengan desa lainnya, dan yang tertinggi diperoleh oleh desa Ntonggu sebesar Rp 892.561.722,9. Untuk mencari penyebab rendahnya transfer dana desa tersebut, berdasarkan wawancara awal dengan informan, dikatakan bahwa untuk Kecamatan Palibelo, desa yang masih tidak memenuhi standar dalam pengelolaan dana desa adalah desa Dore. Dalam praktiknya, desa Dore seringkali menjadi desa dengan tingkat kinerja terendah diantara desa lainnya yang berada dalam satu wilayah kecamatan, dan yang menjadi penyebabnya adalah karena desa Dore seringkali mengalami keterlambatan dalam penyusunan Anggaran Pendapatan dan Belanja Desa (APBDes) serta Laporan Pertanggungjawaban (LPJ) penggunaan dana desa untuk tahun sebelumnya. Menyangkut belum diserahkannya Laporan Pertanggungjawaban, dikarenakan banyaknya pengeluaran yang tidak disertai kwitansi sehingga menghambat penyusunan SPJ, hal ini tentunya akan mempengaruhi proses pencairan dana desa dimana diketahui bahwa beberapa dokumen penting yang harus dilengkapi dalam proses pencairan dana desa (DD) antara lain adalah dokumen RKPDes, dokumen APBDes tahun berjalan, Rencana Penggunaan Uang (RPU), SPJ kegiatan dan dokumen pendukung lainnya.

Dalam pengelolaan dana desa di Desa Dore khususnya yang berkaitandengan Peraturan Bupati Bima Nomor 12 Tahun 2016 Tentang Pedoman Pengelolaan Bantuan Keuangan Pemerintah Daerah Kepada Desa, terdapat beberapa kegiatan/program dalam belanja bidang p emberdayaan masyarakat di Desa Dore 
Ika Asmawati, Prayitno Basuki, dan Ahmad Rifa'i. Kinerja...

yang menyimpang dari peraturan tersebut . Dalam Peraturan tersebut ditegaskan bahwa bantuan keuangan adalah dana bantuan yang bersumber dari daerah kabupaten Bima yang dialokasikan melalui Anggaran Pendapatan Dan Belanja Daerah. Bantuan keuangan desa sebagaimana yang dimaksud dalam Pasal 4 mengkategorikan bantuan keuangan desa menjadi dua jenis bantuan. Pertama, bantuan keuangan umum yaitu bantuan keuangan yang bersumber dari alokasi dana desa (ADD) yang diprioritaskan penggunaannya untuk pemenuhan kebutuhan penghasilan tetap kepala desa dan perangkat desa serta sisanya diarahkan untuk penyelenggaran pemerintahan, pembangunan, pembinaan dan pemberdayaan masyarakat. Kedua, bantuan keuangan khusus yang merupakan kewajiban pemerintah daerah kepada desa yang bersumber dari dana desa (DD) APBN. Dalam pasal 13 ayat 1 dijelaskan beberapa kegiatan yang tidak boleh dibiayai dengan dana bantuan keuangan khusus, antara lain (a) biaya tim/kepanitiaan, (b) lembur, (c) upah tenaga kerja, (d) rapat/sidang, (e) alat tulis kantor, (f) perjalanan dinas, dan (g) biaya penunjang kegiatan lainnya. Namun dalam APBDesa Dore tahun anggaran 2017 beberapa kegiatan/program di atas ternyata dibiayai dengandana bantuan keuangan khusus. Beberapa kegiatan belanja bidang pemberdayaan masyarakat desa yang tertuang dalam APBDesa tahun anggaran 2017 desa Dore yang seharusnya tidak diperbolehkan dibiayai dengan dana bantuan keuangan khusus dapat dilihat pada Tabel 1 berikut.

Tabel.1

Belanja Bidang Pemberdayaan Masyarakat Desa

\begin{tabular}{lll}
\hline No & Jenis Belanja Kegiatan & Jumlah Dana Desa \\
\hline 1 & Honorarium Tim Pelaksana/Pengelola Kegiatan & $\mathrm{Rp} \mathrm{25.500.000}$ \\
2 & Belanja Alat Tulis Kantor & $\mathrm{Rp} 750.000$ \\
3 & Belanja Perjalanan Dinas & $\mathrm{Rp} 200.000$ \\
\hline & Total Belanja & $\mathrm{Rp} \mathrm{26.450.000}$ \\
\hline
\end{tabular}


Sumber: APBDesa tahun anggaran 2017

Berdasarkan tabel diatas dapat diketahui adanya penggunaan dana desa sebesar Rp 26.450.000 dari total dana desa yang dialokasikan untuk belanja bidang pemberdayaan masyarakat desa yaitu $\mathrm{Rp}$ 92.050.695,27 merupakan penyimpangan yang bertentangan dengan Peraturan Bupati Bima Nomor 12 Tahun 2016 Tentang Pedoman Pengelolaan Bantuan Keuangan Pemerintah Daerah Kepada Desa Pasal 13 Ayat 1.

Dalam praktiknya, desa Dore seringkali mengalami keterlambatan dalam penyusunan Anggaran Pendapatan dan Belanja Desa (APBDes) serta Laporan Pertanggungjawaban (LPJ) penggunaan dana desa, hal ini tentunya akan mempengaruhi proses pencairan dana desa yang diketahui bahwa beberapa dokumen penting yang harus dilengkapi dalam proses pencairan dana desa (DD) antara lain adalah dokumen RKPDes, dokumen APBDes tahun berjalan, Rencana Penggunaan Uang (RPU), SPJ kegiatan dan dokumen pendukung lainnya.

Selain itu keterbukaan setiap penggunaan anggaran desa Dore juga dipertanyakan, masyarakat beranggapan pejabat desa manyalahgunakan DDA, karena setiap pekerjaan proyek seperti saluran irigasi dan pembuatan deker dinilai tidak maksimal, ditambah lagi dengan penilaian masyarakat bahwa kegiatan pemberdayaan masyarakat tidak pernah dilakukan oleh Pemerintah Desa dan bertolak belakang dengan apa yang tertera dalam RPJMDesa (www.bimakini.com). Dengan adanya permasalahan ini, mengindikasikan bahwa masyarakat Desa Dore ikut berpartisipasi dalam melakukan penilaian terhadap Kinerja Pemerintah Desa. Bagi setiap organisasi, penilian terhadap kinerja merupakan suatu hal yang penting untuk dapat mengetahui sejauh mana tujuan 
Ika Asmawati, Prayitno Basuki, dan Ahmad Rifa'i. Kinerja...

organisasi tersebut berhasil diwujudkan dalam jangka waktu atau periode tertentu.

Menurut Dwiyanto (dalam Fitri, 2015: 180-192) ada beberapa indikator yang biasanya digunakan mengukur kinerja birokrasi publik, sebagai berikut:

Tabel 2.

Indikator Kinerja

\begin{tabular}{lll}
\hline No & Indikator & Elemen \\
\hline 1 & Produktivitas & $\begin{array}{l}\text { Kualitas pegawai, kemampuan, disiplin kerja } \\
\text { dan kecepatan dalam menyelesaikan pekerjaan. }\end{array}$ \\
2 & Kualitas Layanan & $\begin{array}{l}\text { Penampilan aparatur/petugas dalam melayani } \\
\text { masyarakat, kenyamanan tempat melakukan } \\
\text { pelayanan, dan kemudahan dalam proses }\end{array}$ \\
& pelayanan & Sikap dan komunikasi yang baik, pelayanan \\
& yang tepat dan respon terhadap kritikan/saran \\
3 & Responsivitas & Pertanggungjawaban bawahan terhadap atasan \\
& Repatuhan terhadap prosedur dan \\
5 & Akuntabilitas & pertanggungjawaban terhadap penggunaan dana \\
desa
\end{tabular}

Sumber: Data diolah, 2018

Teori Stewardship bahwa situasi manajemen tidak termotivasi oleh tujuantujuan individu melainkan lebih ditujukan pada sasaran hasil utama mereka untuk kepentingan organisasi (Donaldson, 1989 dan Davis, 1991). stewardship theory mendiskripsikan eksistensi pemerintah desa sebagai organisasi sektor publik yang dapat dipercaya, menampung aspirasi masyarakatnya, memberikan pelayanan yang baik dan dapat mempertanggung jawabkan dana desa yang diamanahkan kepadanya. Sehingga tujuan organisasi untuk mensejahterakan masyarakatnya dapat dicapai secara maksimal. Untuk dapat melaksanakan tanggung jawab tersebut maka pemerintah desa (steward) harus mengarahkan semua kemampuan dan keahliannya secara efektif dan efisien, dengan demikian penilaian masyarakat/ pemerintah daerah/ pemerintah pusat (principal) terhadap pemerintah desa akan sangat memuaskan, dengan hasil yang memuaskan akan menciptakan 
kepuasan bagi pemerintah desa karena Stewardship Theory menggambarkan adanya hubungan yang kuat antara kepuasan dan kesuksesan. Kesuksesan pemerintah desa (steward) yang dinilai oleh principal menunjukan bahwa pemerintah desa bekerja dengan mendahulukan kepentingan organisasi/ lembaga, dan hal inilah yang menjadi dasar dari Stewardship Theory. Dari rangkaian pemahaman demikian, maka penelitian ini menggunakan stewardship theory sebagai landasan kajian.

Penelitian tentang dana desa dilakukan oleh Maumeha, et al (2016) menemukan bahwa kinerja yang ditunjukkan dalam hal akuntabilitas maupun transparansi masih rendah yang disebabkan oleh keterbatasan sumberdaya yang dimiliki oleh perangkat desa. Sedangkan menurut Rosalina (2013) Kinerja Pemerintahan Desa yang baik dapat ditunjukkan dengan indikator akuntabilitas dan transparansi, hasil penelitiannya didukung oleh Nafidah, et al (2015) yang menemukan bahwa pertanggungjawaban Alokasi Dana Desa di Desa Dapurkejambon Kabupaten Jombang baik secara teknis maupun administrasi sudah berjalan dengan baik sesuai peraturan yang berlaku dengan bukti adanya pertanggungjawaban secara tranparan dan akuntabel.

Mengacu pada fenomena, grand teori dan penelitian terdahulu diatas, peneliti mencoba melakukan penelitian untuk mengetahui dan menganalisakinerja Pemerintah Desa Dore Kecamatan Palibelo Kabupaten Bima dalam pengelolaan dana desa, hal ini juga sesuai dengan misi Badan Pemeriksa Keuangan (BPK) melalui pernyataan Wakil Ketua BPK (Bahrullah Akbar) pada Acara Sosialisasi Peran dan Fungsi BPK Dalam Pengawasan Pengelolaan Dana Desa di Kota 
Ika Asmawati, Prayitno Basuki, dan Ahmad Rifa'i. Kinerja...

Mataram yang mengatakan bahwa "BPK telah memformulasikan untuk prioritas pemeriksaan dana desa kedepannya adalah berupa pemeriksaan kinerja" (https://keuangan.com). Menyangkut kebaruan penelitian ini yang membedakan dengan penelitian terdahulu adalah dalam penelitian ini digunakan beberapa elemen untuk mengukur masing-masing dimensi.

\section{METODE PENELITIAN}

Penelitian ini dilakukan di Desa Dore Kecamatan Palibelo Kabupaten Bima yang secara hukum sudah dinyatakan sebagai Desa dalam Peraturan Daerah Kabupaten Bima No 3 Tahun 2006. Ketersediaan akses dan rapport (kedekatan) dengan informan ini sangatlah penting dalam pendekatan interpretif (Cresswell, 2015:123) Rapport dibutuhkan dalam rangka mendalami informasi terkait dalam permasalahan-permasalahan dalam pengelolaan alokasi dana desa yang menjadi dasar penilaian kinerja pemerintah desa. Akses menuju lokasi penelitian seperti itu juga menjadi alasan pemilihan Desa Dore. Memperhatikan pertimbangan pada pendahuluan, penelitian ini diarahkan sebagai jenis penelitian kualitatif dengan pendekatan studi kasus.

Informan sebanyak 5 (lima ) orang, terdiri dari kepala desa, sekretaris desa, bendahara desa, pendamping desa dan masyarakat dengan sumber data primer dan data sekunder. Pengambilan dan pengumpulan data menggunakan teknik pengamatan (observation), wawancara (interview), dan dokumentasi. Selanjutnya data dibahas menggunakan analisis reduksi data, display data, kesimpulan dan verifikasi. Untuk mengetahui kinerja pemerintah desa dalam pengelolaan dana desa di Desa Dore, berpijak pada aspek pertanggung jawaban 
atas amanah yang bersumber dari teori stewardship, penulis menggunakan pendekatan teori Agus Dwiyanto, yaitu dengan melihat pelaksanaan suatu kebijakan berdasarkan 5indikator, yaitu produktivitas, kualitas layanan, responsivitas, responsibilitas dan akuntabilitas.

\section{HASIL DAN PEMBAHASAN}

Desa Dore merupakan pemekaran dari desa Roi, desa Dore adalah salah satu desa di Kecamatan Palibelo Kabupaten Bimaterletak di sebelah selatan ibu kota kecamatan luas wilayah desa Dore adalah $1.87 \mathrm{~km}^{2}$ dan terdiri dari $310,30 \mathrm{Ha}$ wilayah persawahan. 20,43 Ha wilayah pemukiman, 405,22 Ha tegalan dan pekebunan 20,05 Ha perbukitan dan hutan. Jarak tempuh dari desa ke ibu kota kecamatan adalah $5 \mathrm{~km}$ atau 0,20 jam, sedangkan jarak tempuh ke ibu kota kabupaten $24 \mathrm{~km}$ atau 0,30 jam.

Secara administrasi desa Dore adalah salah satu desa yang berada di Kecamatan Palibelo Kabupaten Bima Propinsi NTB. Desa Dore terdiri dari 2 dusun, yaitu: Dusun I, Dusun II, dan memiliki 3 RW, yang terbagi dalam7 RT. Desa Dore memiliki tata pemerintahan yang teridri dari: Kepala Desa, BPD, Seketaris Desa, LPM dan perangkatnya serta Kepala Dusun.

Kinerja pemerintah desa Dore dalam pengelolaan dana desa pada Kecamatan Palibelo Kabupaten Bima dapat dikatakan tidak optimal, dari keseluruhan indikator kinerja yang digunakan yaitu Produktivitas, Kualitas Layanan, Responsivitas, Responsibilitas dan Akuntabilitas, hanya satu faktor yang mencerminkan kinerja baik Pemerintah Desa Dore. Empat (4) faktor lainnya 
Ika Asmawati, Prayitno Basuki, dan Ahmad Rifa'i. Kinerja...

mengalami masalah dan belum berjalan dengan baik dalam pengelolaan dana desa pada desa Dore Kecamatan Palibelo Kabupaten Bima.

Produktivitas merupakan efisiensi dan efektifitas pelayanan pemerintah desa Dore terhadap masyarakat desa. Produktivitas ini juga merupakan suatu hal yang digunakan untuk mengukur sejauh mana kinerja pegawai pemerintah desa dalam pengelolaan dana desa. Produktivitas merujuk pada seberapa besar pelayanan publik memiliki hasil yang diharapkan sebagai salah satu faktor kinerja. Untuk pemerintah desa Dore apabila kinerja dinilai dengan produktivitas, maka ditemukan beberapa hal yang mengindikasikan rendahnya tingkat produktivitas, antara lain:

Dalam hal kualitas pegawai, untuk beberapa jabatan yang penting dalam pengelolaan dana desa pada pemerintah desa Dore tidak diisi oleh aparatur yang memiliki tingkat pendidikan mumpuni, artinya bahwa antara tanggungjawab dengan tingkat pendidikan tidak seimbang. Hal ini dibuktikan dengan hasil wawancara terhadap informan 3 "Sebenarnya saya siapa si? Saya hanya lulusan sekolah dasar saja, tapi bisa dipercaya pegang jabatan ini, Alhamdulillah" Pernyataan informan di atassama halnya dengan informan 4 "belum lulus sarjana saya, sejak tahun 2011 saya kuliah, tapi belum bisa selesai sampai saat ini”"

Kemampuan yang sesuai dengan bidangnya akan meningkatkan produktivitas aparatur desa. Berdasarkan hasil wawancara dengan beberapa informan, sama halnya dengan kualitas pegawai bahwa beberapa orang aparatur dalam pemerintah desa Dore tidak memiliki kemampuan yang kompeten dalam bidangnya, berikut pernyataan informan 4 "Hanya kendala kalau keterlambatannya yang 
mengkhawatirkan, kita belum bisa bikin pembukuan, sistem itu berubah-ubah, saya sebagai pribadi kadang sulit menerima perubahan itu dengan mudah "kalau saya jika tidak ada contoh tidak bias dengan mudah paham”, saya kan sebelumnya bukan bendahara, pegawai biasa dan lulusan SMA”.

Pernyataan informan 4 sejalan dengan pernyataan informan 2 “Jujur saya juga di Desa ini baru artinya pengalaman terkait dengan adminstrasi nol, saya ini sebelumnya guru honorer, kalau terkait UU Alhamdulillah tapi secara administrasi masih nol dan masih perlu belajar"

Terdapat beberapa pernyataan dari informan yang menunjukkan kurangnya disiplin kerja aparatur pemerintah desa Dore,pernyataan tersebut berasal dari informan 3 "Memang dalam UU no 6 tahun 2014 Kepala Desa diberikan hak akan tetapi Kepala Desa melimpahkan hak nya kepada Bendahara Desa yang nantinya Bendahara Desa akan melaporkan kepada Kepala Desa namun selama ini Bendaharanya jarang berada di Kantor"

Pernyataan lain yang menunjukkan hal serupa berasal dari informan 5 “Sejak kapan Kepala Desa berada di Kantor Desa? seringkali Kepala Desa tidak berada di tempat, dan yang rajin berada di Kantor hanya Sekretaris Desa”

Pernyataan informan 5 dipertegas oleh informan 1 "Kalau aturan seharusnya Kepala Desa yang paling tahu Dana Desa itu dipakai untuk apa saja, tapi Kepala Desa kalau cari di Kantor susah ketemu”

Pemerintah desa Dore belum dapat menunjukkan bahwa aparatur desa mampu menyelesaikan pekerjaannya sesuai dengan waktu yang telah ditetapkan. Dalam pembuatan laporan pertanggungjawaban dana desa, diakui oleh aparatur 
Ika Asmawati, Prayitno Basuki, dan Ahmad Rifa'i. Kinerja...

desa seringkali mengalami keterlambatan, hal ini merujuk pada pernyataan informan 4 "Hanya saja kendala dalam keterlambatannya itu yang mengkhawatirkan, kami belum bisa membuat pembukuan karena sistem itu selalu mengalami perubahan, saya sebagai pribadi terkadang sulit menerima perubahan itu dengan mudah"

Responsivitas adalah kemampuan pegawai pemerintah desa Dore Kecamatan Palibelo Kabupaten Bima untuk mengenali apa yang menjadi keinginan masyarakat, dan kemampuan untuk menyusun agenda prioritas pelayanan dalam mengembangkan program - program pelayanan masyarakat sesuai dengan kebutuhan dan aspirasi masyarakat Desa. Secara singkat responsivitas mempunyai arti kejelasan antara program dan kegiatan pelayanan dengan kebutuhan dan aspirasi masyarakat, Responsivitas yang rendah ditunjukkan dengan ketidak keselarasan antara pelayanan dan kebutuhan publik.

Responsivitas yang baik akan berpengaruh terhadap pengelolaan dana desa Dore dalam melaksanakan pelayanan terhadap masyarakat. Sehingga kinerja dalam berbagai bidang sangat diharapkan dapat berjalan dengan baik sesuai dengan apa yang menjadi harapan pemerintah desa Dore. Oleh karena itu, faktor responsivitas aparatur menjadi salah satu faktor yang sangat penting untuk ditingkatkan demi berjalannya pengelolaan dana desa dalam pelayanan terhadap masyarakat desa Dore. Beberapa hal yang harus diperhatikan dalam menentukan tingkat responsivitas pemerintah desa Dore adalah: 
Petugas/ aparatur melakukan pelayanan dengan tepat, artinya pelayanan yang diberikan sesuai dengan keinginan masyarakat sehingga tidak ada yang merasa dirugikan atas pelayanan yang didapat.

Dalam pengelolaan dana desa, pemerintah desa Dore terbuka dalam hal menampung aspirasi masyarakat, artinya apa yang menjadi keinginan masyarakat akan diakomodir dan dijadikan pertimbangan. Berdasarkan hasil wawancara dengan informan 5 "Apa saja yang diinginkan masyarakat ditampung, musyawarah selalu ada, tidak dimusyawarahkan sendiri saja, malah kadang kalau ada salah satu masyarakat yang punya acara, masyarakat lainnya dihimbau supaya datang, apa saja yang menjadi saran atau kritik bisa diungkapkan secara langsung”

Pernyataan informan 5 sejalan dengan pernyataan informan 2 "Kita sudah melakukan musyawarah Desa artinya apa yang menjadi usulan masyarakat itu kita tampung tidak semua yang diusulkan mampu disesuaikan dengan anggaran ada tim yang melakukan verifikasi terhadap usulan dari masyarakat itu, Alhamdulillah kemarin kita sudah melakukan musyawarah tim disitu kita buka apa yang menjadi usulan masyarakat dari empat bidang yaitu bidang pemerintahan,bidang pembangunan, bidang pemberdayaan dan bidang pembinaan. Dan yang dipilih itu berdasarkan skala prioritas yang diusulkan”.

Semua keluhan/kritik masyarakat direspon, bahwa pemerintah desa harus menyediakan akses kepada masyarakat untuk dapat menyampaikan keluhan/kritik dan dapat dicarikan solusi terbaik. 
Ika Asmawati, Prayitno Basuki, dan Ahmad Rifa'i. Kinerja...

Dalam menanggapi adanya keluhan/kritikan dari masyarakat mengenai dana desa, pemerintah desa Dore sudah dapat merespon dengan baik, dapat dilihat dari hasil wawancara dengan informan 2 "Kritikan atau protes, kalau selama ini, kalau di Dore baru satu kali itupun melalui surat dan ada forum anak muda, bukan karang taruna kebetulan muncul seketika forum itu, mereka ingin tatap muka langsung dengan kami di desa terkait dengan anggaran desa ini, dan kami mengikuti keinginan mereka”

Merespon setiap masyarakat yang ingin mendapatkan pelayanan, mencakup sikap dan komunikasi yang baik dari aparatur pemerintah desa. Pemerintah desa Dore dapat mengenali apa yang menjadi keinginan masyarakat, dan sesuai dengan kebutuhan/aspirasi masyarakat desa Dore. Keinginan atau aspirasi masyarakat desa diakomodir dengan baik oleh pemerintah desa Dore, hal ini dipertegas melalui hasil wawancara dengan informan 3 "Sedangkan yang namanya RPJM itu sama halnya dengan visi misi Kepala Desa, akan tetapi bukan berarti visi misi itu semua harus dilaksanakan, namun kebutuhan masyarakat lain berdasarkan usulan tersebut harus dilaksanakan, karena apa? dalam RKPDesa itu oleh tim 9 harus dibuat dengan nomor masalah skala prioritas, kenapa skala prioritas? blum tentu usulan masyarakat yg banyak itu cocok dengan anggaran makanya yang diprioritaskan yang mana dulu, andaikan ada usulan yang tidak bisa dijangkau oleh anggaran 2018 jadi 2019 harus diprioritaskan yg ini yang tujuannnya jangan sampai nanti masyarakat bilang usulan mereka tidak direspon" 
Kualitas layanan cenderung menjadi sangat penting dalam menjalankan organisasi pelayanan publik. Banyak pandangan negatif yang terbentuk mengenai kinerja pegawai yang muncul karena ketidakpuasan masyarakat dalam pelayan Publik. Hal ini seperti yang terjadi di pemerintah desa Dore kecamatan Palibelo kabupaten Bima. Berkualitas tidaknya pelayanan yang diberikan ini akan berpengaruh pada kinerja pegawai di pemerintahan desa. Dengan demikian keputusan masyarakat terkait masalah kualitas layanan dapat dijadikan faktor kinerja organisasi. Kualitas layanan yang dimiliki oleh pemerintah desa Dore ini dapat dijadikan salah satu indikator dalam mengukur kinerja pegawai pemerintah desa Dore. Beberapa hal yang digunakan sebagai dasar dalam menilai kualitas layanan dalam penelitian ini:

Berdasarkan hasil observasi di Lapangan, dapat disimpulkan bahwa dalam hal penampilan petugas/aparatur dalam melayani masyarakat, Pemerintah desa Dore belum optimal, hal ini terlihat dari beberapa aparatur desa yang berpenampilan santai tanpa seragam formal pada saat jam kerja. Hasil observasi ini juga dipertegas oleh hasil wawancara informan 2 "Begitulah Kepala Desa dan Bendahara sama saja, tidak pernah memakai seragam kerja, mereka lebih santai".

Sama halnya dengan penampilan petugas/ aparatur, kenyamanan tempat melakukan pelayanan juga dapat dinilai dengan melakukan observasi langsung, berdasarkan hasil observasi, bangunan Kantor Desa Dore adalah bangunan lama yang bisa dikatakan sudah tidak layak digunakan sebagai Kantor Desa. Dalam hal kemudahan proses pelayanan, untuk pemerintah desa Dore dapat dikatakan tidak 
Ika Asmawati, Prayitno Basuki, dan Ahmad Rifa'i. Kinerja...

optimal. Jika dikaitkan dengan ketidak disiplinan aparatur desa maka akan mempengaruhi kemudahan dalam proses pelayanan tersebut.

Responsibilitas dalam sebuah organisasi pemerintahan merupakan hal yang sangat penting. Sebab responsibilitas ini menyangkut masalah prinsip-prinsip organisasi, administrasi yang benar atau sesuai dengan kebijakan yang telah diambil oleh organisasi pemerintahan. Reponsibilitas yang baik tentunya akan membuat kinerja yang baik begitupun sebaliknya. Hasil wawancara dengan informan 3 mengatakan "Memang dalam UU no 6 tahun 2014 Kepala Desa diberikan hak,hanyaKepala Desa melimpahkan hak nya itu kepada Bendahara Desa dan nanti Bendahara Desa melaporkan pada Kepala Desa tapi selama ini Bendaharanya jarang di Kantor”.

Berdasarkan hasil wawancara terdapat pelimpahan sebagian tugas kepala desa kepada bendahara. Berkaitan dengan hal itu, secara administrasi memunculkan kewajiban bagi bendahara untuk mempertanggungjawabkan pekerjaannya kepada kepala desa.Selanjutnya, mengacu pada pernyataan lain dari informan 3 "Ada keluhan keterlambatan dari pemda, saya tidak bisa apa-apa, ini semua bisa terjadi karena bendahara tidak begitu gesit dalam menangani dan melaporkan permasalahannya kepada saya. Ketika saya bertanya mengenai SPJ, pajak dan yang lainnya, saya hanya memperoleh jawaban "sedikit lagi". Akan tetapi begitu diperiksa inspektorat ternyata tidak benar hal hal inilah yang sering terjadi"

Pernyataan informan 3 mengindikasikan rendahnya responsibilitas aparatur desa yang diukur melalui pertanggungjawaban bawahan terhadap atasan, dalam 
hal ini bendahara sebagai bawahan kepala desa tidak melaksanakan kewajibannya dengan baik. Akan tetapi, wawancara yang dilakukan dengan informan 4 menunjukkan alasan yang memungkinkan menjadi penyebab rendahnya responsibilitas tersebut "Apapun yang diminta tetap kita penuhi walaupun terlambat tetap kita penuhi, terkadang namanya rumah tangga ada masalah komunikasi itu yang bikin terlambat”.

Akuntabilitas mengandung arti berapa besar kegiatan organisasi publik tunduk pada para aparat desa yang dipilih rakyat, asumsinya adalah kepala desa dipilih oleh rakyat. Dengan sendirinya akan selalu merepresentasikan kepentingan rakyat dan akuntabilitas ini pula merupakan suatu ukuran yang menunjukkan berapa besar tingkat kesusuaian penyelenggara pelayanan dengan ukuran nilainilai atau norma-norma eksternal yang ada dipublik atau yang dimiliki beberapa stakeholder. Oleh karena itu, faktor akuntabilitas ini menjadi hal yang sangat penting dimiliki setiap organisasi pemerintahan maupun instansi lainnya sebab akuntabilitas ini juga termasuk didalamnya tanggung jawab. Sehingga kinerja pemerintah Desa Dore Kecamatan Palibelo Kabupaten Bima ini menjadi baik dan ini tergantung pula pada akuntabilitas yang dimiliki. Maka dari itu, untuk mengetahui seperti apa akuntabilitas yang di miliki aparat pegawai pemerintah desa Dore, peneliti mewawancarai beberapa informan sebagai berikut: informan 2 "Buku Kas Masuk, Buku Pajak dan Buku Bank semuanya sudah ada, tetapi tidak difungsikan dengan baik oleh Bendaharanya”

Berdasarkan hasil wawancara dapat dikatakan Pemerintah Desa Dore dalam pengelolaan dana desa tidak menunjukkan kepatuhan terhadap prosedur, artinya 
Ika Asmawati, Prayitno Basuki, dan Ahmad Rifa'i. Kinerja...

bahwa secara prosedur, beberapa hal yang menyangkut penerimaan dan pengeluaran seharusnya dicatat pada rekening tertentu, akan tetapi dalam praktiknya tidak semua penerimaan dan pengeluaran dalam rangka pelaksanaan kewenangan Desa melalui Rekening Kas Desa. Akuntabilitas yang diukur dengan pertanggungjawaban terhadap penggunaan dana desa juga tidak dapat dipenuhi oleh Pemerintah Desa Dore karena seringkalipengeluaran yang dibelanjakan tidak disertai kuitansi yang sah. Berikut hasil wawancara yang mendukung pernyataan sebelumnya. "Saya pernah katakan, kalau memang tidak bisa membuat SPJ gantikan dengan laporan saja seperti surat pernyataan bahwa Bendahara hanya mengetahui uang keluar, tanpa ada kuitansi”.

Beberapa kutipan hasil wawancara dapat digunakan sebagai dasar dalam menjustifikasi tingkat kinerja pemerintah Desa Dore. Secara umum, kinerja pemerintah Desa Dore dinilai rendah, berdasarkan temuan penelitian rendahnya kinerja tersebut dikarenakan faktor sumber daya manusia yang tidak optimal. Hasil penelitian ini mendukung penelitian Maumeha, et al (2016) dan Fitri (2015) yang menemukan bahwa sumber daya manusia menjadi faktor penyebab rendahnya akuntabilitas dan responsibilitas.

\section{SIMPULAN}

Berdasarkan faktor responsivitas kinerja pemerintah desa Dore dapat dinilai atau dikatakan sudah baik karena mengutamakan kebutuhan dan aspirasi masyarakat. Faktor produktivitas yang diukur dengan kualitas pegawai, kemampuan, disiplin kerja dan cepat dalam menyelesaikan pekerjaan menunjukkan kinerja pemerintah desa Dore yang rendah. Faktor kualitas pelayananjugamenunjukkan kinerja 
pemerintah desa Doreyang rendah apabiladinilai dari sisipenampilan petugas/aparatur dalam melayani masyarakat, kenyamanan tempat melakukan pelayanan dan kemudahan dalam proses pelayanan. Berikutnya, faktor akuntabilitas dapat dinilai masih rendah ketika diamati bahwa aparat desa kurang transparan dalam pelaksanaan program kegiatan dana desa, banyak program/kegiatan yang menggunakan biaya bersumber dari dana desa yang tidak dilengkapi kuitansi dan SPJ. Selain itu, berkaitan dengan penerimaan dan pengeluaran pemerintah desa, yang secara aturan seharusnya dicatat dalam buku bank akan tetapi pemerintah desa Dore diwakili oleh bendahara desa tidak dapat memanfaatkan buku bank tersebut sesuai fungsinya. Dan, untuk faktor responsibilitas pemerintah desa Dore juga dinilai belum dapat menunjukan kinerja yang optimal dikarenakan tingkat pertanggungjawaban bawahan terhadap atasannya masih rendah.

Saran yang diberikan oleh peneliti kepada pemerintah Desa Dore adalah dari segi kualitas perlunya Pendidikan dan Pelatihan untuk aparat Desa dalam penatausahaan dan pengelolaan dana desa, sehingga akan ikut meningkatkan kualitas sumber daya manusia. Penambahan pegawai desa dapat dilakukan dengan cara merekrut tenaga kontrak atau tenaga lepas. Transparansi dapat dilakukan dengan menyediakan media yang dapat dengan mudah diakses oleh masyarakat sebagai salah satu bentuk pertanggungjawaban pengelolaan dana desa 


\section{REFERENSI}

Anak Administrasi Pendidikan. 2016. Produktivitas Kerja Pegawai. (https://gooddaycheese.wordpress.com) diakses tanggal 21 Nopember 2018

Creswell, Jhon W. 2015. Research Design, Pendekatan Kualitatif, Kuantitatif dan Mixed. Pustaka Belajar

Fitri. 2015. Kinerja Pemerintah Desa Dalam Pengelolaan Dana Desa Pada Desa Vatunonju Kecamatan Biromaru Kabupaten Sigi. e-jurnal katalogis. Volume 3. Hal 180-192

Hadiman, Suhendra. 2017. 53132340-Kinerja-pemerintah-dalampengelolaan-alokasi-dana-desa-suatu-studi-di-desa-dokulamokecamatan-galela-barat.html. (http://docplayer.info) diakses tanggal 16 Juli 2018

Hermawan, Wawan. 2016. Indikator Kualitas Pelayanan.html. (https://prastyahermawanprayoga.blogspot.com) diakses tanggal 21 Nopember 2018

Hilmi, Abdullah. 2018. BPK Sosialisasi Pengelolaan dan Pengawasan Dana Desa. (https://www.keuangan.com) diakses tanggal 5 Mei 2018

Media. 2017. Buku Pintar Dana Desa.pdf. (https://www.kemenkeu.go.id) diakses tanggal 10 Januari 2018

Nafidah, Lina Nasehatun. 2015. Akuntabilitas Pengelolaan Keuangan Desa di Kabupaten Jombang.Jurnal Ilmu Akuntansi

Prayitno, Panji. 2017. Empat Syarat Agar Dana Desa 2018 Bisa Cair. (https://www.mliputan6.com) diakses tanggal 3 Maret 2018

Redaksi. 2017. Pemuda Menuding Kades Menjawab. (https://www.bimakini.com) diakses tanggal 3 Maret 2018

Redaksi. 2018. Dana Desa Bermasalah P3MD NTB Sebut Pengelola Kurang SDM. (https://www.lombokita.com) diakses tanggal 3 Maret 2018

Republik Indonesia. 2004. Undang-Undang No. 32 Tahun 2004 tentang Pemerintahan Daerah. Jakarta 2014. Undang-Undang No. 6 Tahun 2014 tentang Desa. Jakarta 
1979. Undang-Undang No. 5 Tahun 1979 tentang Pemerintahan Desa. Jakarta

2017. Undang-Undang No. 19 Tahun 2017 tentang Prioritas Dana Desa

2006. Peraturan Daerah Kabupaten Bima No. 3 Tahun 2006.Kabupaten Bima

Rosalinda LDP, Okta. 2014. Pengelolaan Alokasi Dana Desa (ADD) Dalam Menunjang Pembangunan Pedesaan. Portalgaruda.org/artikel

Sofiyanto, et al. 2016.Pengelolaan Dana Desa Dalam Upaya Meningkatkan Pembangunan Di Desa Banyuates Kecamatan

Sugiyono. 2014. Metode Penelitian Kuantitatif Kualitatif dan R\&D. Penerbit Alfa Beta: Bandung

Wp-content/uploads. 2018. KepmenDesaPDTT-Nomor-48-tahun-2018-ttgPedoman-Umum-Program-Inovasi-Desa-Salinan.pdf.

(https://www.berdesa.com) diakses tanggal 16 Juli 2018

Mahsun, $\quad$ Moh. 2011. akuntabilitas-kinerja.html. (http://mohmahsun.blogspot.com) diakses tanggal 21 Nopember 2018 